\title{
EFEKTIFITAS CHILD CENTERED PLAY THERAPY UNTUK MENINGKATKAN KEMAMPUAN JOINT ATTENTION PADA ANAK AUTISM SPECTRUM DISORDER
}

\author{
Maria Novitawati ${ }^{1}$ Ediasri Toto Atmodiwirjo ${ }^{2}$, Debora Basaria ${ }^{3}$ \\ ${ }^{1}$ Fakultas Psikologi, Universitas Tarumanagara Jakarta \\ Email: marianovita014@gmail.com \\ ${ }^{2}$ Fakultas Psikologi, Universitas Tarumanagara Jakarta \\ Email: ediasri@gmail.com \\ ${ }^{3}$ Fakultas Psikologi, Universitas Tarumanagara Jakarta \\ Email: deborabasariayulianti@gmail.com
}

\begin{abstract}
ABSTRAK
Anak Autism Spectrum Disorder (ASD) kesulitan mengembangkan dan menumbuhkan kemampuan sosial dan emosi dalam pola yang sama dengan perkembangan anak seusianya. Anak ASD seringkali memiliki kesulitan untuk menginisiasi sebuah permainan dan secara umum tidak menyukai interaksi sosial timbal balik. Defisit joint attention merupakan core yang ditampilkan oleh anak ASD dalam kriteria DSM 4 (APA,1994). Child Centered Play Therapy (CCPT) adalah terapi yang memiliki salah satu area tujuannya yaitu joint attention. Penelitian sebelumnya menyebutkan, CCPT dapat efektif untuk meningkatkan kemampuan joint attention sehingga meningkatkan kemampuan berinteraksi sosial bagi anak dengan ASD. Tujuan penelitian ini adalah mengetahui efektivitas CCPT untuk meningkatkan kemampuan Joint Attention pada anak ASD sehingga mampu merespon dan terlibat dalam lingkungan sosial. Desain penelitian ini menggunakan metode kuantitatif dengan single case-experiment pre-testpost-test design dengan mengukur skor kemampuan joint attention meliputi kemampuan inisiative joint attention (IJA) dan kemampuan response joint attention (RJA) pada anak ASD dengan usia tiga tahun saat sebelum dan sesudah diberikan CCPT. CCPT diberikan sebanyak dua puluh sesi terapi selama empat minggu. Berdasarkan hasil penelitian yang dilakukan, ditemukan bahwa Child Centered Play Therapy (CCPT) dapat meningkatkan inisiative joint attention (IJA) dengan perbandingan skor pada post-test lebih tinggi $(77,56)$ dibandingankan dengan pre-test $(38,12)$.
\end{abstract}

Kata kunci: joint attention, autism spectrum disorder, child centered play therapy

\section{PENDAHULUAN}

Menurut DSM V (APA, 2013), anak dengan Autism Spectrum Disorder (ASD) adalah anak yang memiliki kekurangan menetap pada kemampuan berinteraksi sosial, komunikasi, dan memiliki pola perilaku yang kaku dan berulang. Kriteria kekurangan dalam kemampuan komunikasi meliputi buruknya integrasi komunikasi vebal dan non verbal, pada kemampuan komunikasi nonverbal yang digunakan untuk berinteraksi sosial. Sebagai contoh, kontak mata dan bahasa tubuh yang abnormal atau keterlambatan dalam memahami dan menggunakan gestur; sampai ketidakmampuan total untuk melakukan ekspresi wajah dan komunikasi nonverbal (APA, 2013). Secara keseluruhan, awal keterlambatan perilaku sosial muncul setidaknya pada lima area perilaku sosial yaitu orientasi pada rangsang sosial, joint attention, emosi, imitasi, dan face processing (Dawson \& Faja dalam Nelson \& Israel, 2015). Inti gangguan yang ditampilkan oleh anak dengan ASD adalah defisit joint attention (Kerig, Ludlow \& Wenar, 2012). Defisit joint attention merupakan core yang ditampilkan oleh anak ASD dalam kriteria DSM 4 (APA,1994), termasuk kurangnya spontanitas dalam berbagi kesenangan, minat, atau mencapai sesuatu bersama orang lain.

Joint attention mengacu pada kapasitas anak untuk mengkoordinasikan perhatian pada patner sosial di sekeliling benda maupun pada suatu kejadian tertentu dan terobservasi ketika anak memperlihatkan secara terbuka keterampilan seperti alternatif pandangan antara obyek dengan orang dengan menunjuk, memperlihatkan, atau memberikan (Mundy \& Sigman; Scaife \& Bruner, dalam Kaale, Smith, \& Sponheim, 2012). 
Menurut fungsinya, joint attention diidentifikasikan menjadi dua tipe yaitu untuk merespon dan untuk berinisiatif. Anak mengikuti orang lain yang berusaha mengkoordinasikan atensi yang ditujukan pada obyek atau kejadian tertentu dengan memperlihatkan atau mengganti pandangan diketahui sebagai respon dari joint attention (Naoi et al. dalam Jeyabalan, 2012). Bentuk yang kedua dari joint attention adalah inisiatif untuk meminta, memberi (give), memperlihatkan (show), dan menunjuk (point) (Rudy et.al, 2014; Kaale, Smith, \& Sponheim, 2012).

Beberapa ahli yang menangani anak dengan ASD telah menganjurkan untuk melakukan intervensi dengan basis bermain (Gallo-Lopez \& Rubin; Greenspan \& Weider; Layne dalam Balch \& Ray, 2015), yang memberikan suport pada penggunaan terapi bermain sebagai metode dalam treatment bagi anak dengan ASD (Balch \& Ray, 2015). Pada studi yang dilakukan oleh Kasari (2006), telah diuji kemampuan intervensi dengan target joint attention dan bermain simbolik. Hasil dari penelitian ini, anak yang diberikan intervensi joint attention secara signifikan menginisiasikan lebih memperlihatkan dan mengekspresikan joint attention pada saat pengukuran terstruktur joint attention dan anak menginisiasikan joint attention pada interaksi ibu dan anak (Kasari, 2006).

Pada penelitian sebelumnya yang dilakukan oleh Kaale, Smith, dan Spoheim (2012) yang berfokus pada peningkatan inisiatif dari higher order joint attention yaitu show (memperlihatkan), point (menunjuk), dan give (memberi), untuk memberikan kesempatan mau menginisiasi joint attention, digunakan mainan yang menarik bagi anak (atau obyek) dengan cara memperlihatkan mainan, atau menyembunyikan mainan untuk merangsang inisiatif joint attention.

Bermain adalah sebuah cara anak-anak autisme berkomunikasi (Kerig, Ludlow, \& Wenar, 2012). Play therapy dapat merupakan metode treatment yang efektif untuk anak dengan spektrum autis yang memiliki kesulitan komunikasi verbal dan kurangnya ketrampilan kognitif. Melalui childcentered perspective, anak dengan ASD diberikan tantangan untuk memiliki relasi (Ray, Sullivan, \& Carlson dalam Balch \& Ray, 2015).

Child-Centered Play Therapy (CCPT) adalah sebuah intervensi berbasis hubungan di mana anak ASD dapat memiliki kesempatan untuk merasa diterima sepenuhnya oleh konselor, sebuah kondisi yang seringkali tidak tersedia bagi mereka (Ray et al. dalam Balch \& Ray, 2015). Josefi dan Ryan (dalam Salter, Beamish, \& Davies, 2016) telah secara khusus mengidentifikasikan empat area tujuan dari intervensi Child-Centered Play Therapy yaitu joint attention, meniru respon, theory of mind, dan keterampilan fungsi dan simbol dalam bermain. Peran joint attention dalam perkembangan bahasa adalah salah satu alasan penting untuk menjadikannya target intervensi pada masa awal perkembangan. (Clifford \& Dissanayake, 2009; Gillespie-Lynch et al. dalam Schertz et al., 2013).

Terdapat sebuah studi intervensi dengan kontrol randomisasi mengukur joint attention dan symbolic play yang dilakukan oleh Kasari, Stephany, dan Paparella (2005) pada 58 anak dengan ASD yang berusia 3 dan 4 tahun. Hasil penelitian menunjukkan bahwa anak yang memperoleh intervensi joint attention dan symbolic play lebih banyak menampilkan inisiatif dan respon joint attention saat dilakukan pengukuran joint attention

Dalam perkembangan CCPT, menurut Salter, Beamish. \& Davies (2016), area terapi individual dengan menggunakan CCPT kurang diteliti. Studi literatur secara koprehensif menyatakan 
bahwa terdapat hanya ada empat penelitian yang telah dilakukan saat ini. Pada penelitian ini, permasalahan yang akan diteliti adalah efektivitas dari Child Centered Play Therapy untuk meningkatkan kemampuan joint attention, yaitu kemampuan respon dan inisiatif joint attention.

Anak-anak dengan autisme mengalami masalah yang serius dengan dunia sosial (Dawson et al., 2004 dalam Kring, Johnson, Davison, \& Neale, 2010). Anak-anak dengan autisme menunjukkan kurang berkembangnya gestur dalam berkomunikasi yang berat (Kerig, Ludlow, \& Wenar, 2012). Defisit joint attention merupakan core yang ditampilkan oleh anak ASD dalam kriteria DSM IV (APA,1994) termasuk kurangnya spontanitas dalam berbagi kesenangan, minat, atau mencapai sesuatu bersama orang lain.

Joint Attention adalah kapasitas seseorang untuk menggunakan gestur dan kontak mata untuk mengkoordinasikan perhatian dengan orang lain dalam rangka untuk berbagi pengalaman yang menarik terkait benda disekitar atau kejadian yang dialami seseorang (Mundy, Sigman \& Kasari dalam Jeyabalan, 2012).

Studi literatur menyatakan bahwa dua komponen joint attention yaitu respon joint attention dan inisiatif joint attention merupakan inti perkembangan yang harus diupayakan pada anak dengan ASD (Lynch, 2013). Pola yang defisit disini terdapat pada inisiatif komunikasi untuk joint attention yang muncul sebagai tanda dari anak ASD. Anak ASD kurang menunjukkan pergantian pandangan, menghabiskan waktu yang lebih sedikit untuk ikut serta atau bergabung dengan orang lain, dan memiliki kesulitan yang mengikuti fokus pandangan orang lain kemana mereka melihat atau menunjuk (Sigman et al.; Stone, Ousley, Yoder et al. dalam Charman \& Wendy, 2006). Defisit dalam inisiasi dan merespon joint attention akan menjadi daftar efek dari perkembangan bahasa, karena belajar bahasa terjadi melalui konteks modelling dari kata-kata yang diucapkan caregiver yang ditujukan pada obyek dan situasi dimana terjadi joint antara anak dengan caregiver.

Bermain adalah sebuah cara anak-anak autisme berkomunikasi. Bagaimanapun, tidak seperti anak-anak pada umumnya, perilaku anak dengan autisme dalam bermain adalah kurangnya fungsi sosial dan simbolis. Contohnya, ketika bermain, anak-anak diberikan balok-balok, anakanak pada umumnya akan menjadikan balok tersebut seperti mobil. Anak dengan autisme, umumnya, cenderung akan menjajarkan balok-balok tersebut dengan lurus atau dalam barisan, memutar-mutarnya, dan memerhatikannya (Kerig, Ludlow, \& Wenar, 2012).

Josefi dan Ryan (dalam Salter, Beamish, \& Davies, 2016) telah secara khusus mengidentifikasikan empat area tujuan dari intervensi CCPT, yaitu joint attention, meniru respon, theory of mind, dan keterampilan fungsi dan simbol dalam bermain. Keterampilan yang berkontribusi pada kemampuan komunikasi sosial secara khusus digambarkan dalam kapasitas pada seksi joint attention dan penggunaan simbol (Charman \& Wendy, 2006). Defisit joint attention merupakan core yang ditampilkan oleh anak ASD dalam kriteria DSM IV (APA,1994) termasuk kurangnya spontanitas dalam berbagi kesenangan, minat, atau mencapai sesuatu bersama orang lain.

Bermain biasanya diketahui harus memiliki fungsi organisasi kognitif, merefleksikan perbedaan tahap perkembangan (Piaget, Wilson \& Ryan dalam Salter, Beamish, \& Davies, 2016). Tahap perkembangan ini disuport dalam intervensi CCPT yang membantu pemahaman anak untuk mengeksplorasi dan mengintegrasikan konstruk ini dalam langkah mereka. Oleh karena itu, intervensi CCPT dapat menyediakan input langkah perkembangan anak secara tepat melalui 
empat area penting (joint attention, meniru respon, theory of mind, dan keterampilan fungsi dan simbol dalam bermain) dengan menggunakan suport dari ketrampilan yang dimiliki terapis. Bagaimanapun, selain adanya perkembangan secara umum dalam intrvensi CCPT, area individual antara anak dengan ASD dan CCPT sangat sedikit diteliti (Salter, Beamish, \& Davies, 2016).

\section{METODE PENELITIAN}

Subyek penelitian. Kriteria subyek pada penelitian ini adalah seorang anak berusia 3 tahun dengan jenis kelamin laki-laki, yang telah didiagnosa Autis Spectrum Disorder (ASD). Subyek memiliki kemampuan noverbal seperti kontak mata terhadap benda dan terhadap orang lain yang masih terbatas (kurang), namun belum mampu melakukan pergantian kontak antara benda dengan orang lain. Subyek hanya mampu memahami perintah sederhana seperti "salam" dan "tos". Subyek belum pernah mengikuti Child Centered Play Therapy dimanapun.

Metode peneltian. Metode penelitian ini menggunakan metode kuantitatif dengan single caseexperiment pre-test-post-test design. Pendekatan tersebut digunakan karena penelitian ini menggunakan satu subyek dalam penelitian (Shaughnessy, Zechmeister, \& Zechmeister, 2015).

Design penelitian. Design yang digunakan dalam single case-experimental ini adalah ABA. Tahap pertama pada penelitian ini adalah baseline stage (A), tahap kedua adalah tahap treatment (B) yaitu intervensi CCPT, dan ketiga subyek kembali pada evaluation stage (A).

Pengukuran. Subyek diberikan assesment melalui Childhood Autism Rating Scale (CARS) dan Denver Developmental Screening Test (DDST). Kemudian subyek diberikan pre-test dan posttest melalui Early Social Communication Scale (ESCS) oleh Mundy et al (2003) digunakan untuk mengukur kemampuan joint attention pada subyek.

Prosedur penelitian. Tahap baseline (A) menggunakan The Early Social Communication Scales (ESCS). Observasi joint attention menggunakan ESCS oleh penilai ESCS melalui teknis merekam dengan menggunakan video. Tahap intervensi dilakukan menggunakan CCPT, intervensi CCPT diberikan dalam 20 sesi, yang dilakukan 5 kali dalam satu minggu selama 4 minggu. CCPT dilakukan secara individual selama masing-masing 60 menit /sesi/ hari oleh peneliti dengan menggunakan prosedur dan struktur dari Mullen dan Rickli (2014). Tahap evaluasi (A) menggunakan The Early Social Communication Scales (ESCS). Observasi joint attention menggunakan ESCS oleh penilai ESCS melalui teknis merekam dengan menggunakan video.

\section{HASIL DAN PEMBAHASAN}

Pada tahap baseline, perbandingan kemampuan subyek pada Joint Attention (JA), Behavior Request (BR), dan Social Interaction (SI) yang diukur melalui ESCS. Tabel 1 menunjukkan hasil pengukuran ESCS tahap baseline. 
Tabel 1. Hasil Pengukuran ESCS tahap baseline

\begin{tabular}{ccccc}
\hline No & Kemampuan & Hasil rata-rata & Nilai rata-rata & $\begin{array}{c}\text { Perbandingan } \\
\text { kemampuan }\end{array}$ \\
\hline 1 & IJA & 38.12 & 33.74 & $>33.74$ \\
2 & RJA & 27.5 & 33.74 & $<33.74$ \\
3 & IBR & 37.4 & 33.74 & $>33.74$ \\
4 & RBR & 45 & 33.74 & $>33.74$ \\
5 & ISI & 31.25 & 33.74 & $<33.74$ \\
6 & RSI & 23.17 & 33.74 & $<33.74$ \\
\hline
\end{tabular}

Keterangan :

IJA : Inisiative Joint Attention

RJA : Responding Joint Attention

IBR : Inisiative Behavior Request

RBR : Responding Behavior Request

ISI : Inisiative Social Interaction

RSI : Responding Social Interaction

Kemampuan IJA, IBR, dan RBR berada diatas rata-rata kemampuan komunikasi sosial yang diukur melalui ESCS, dan kemampuan RJA, ISI, dan RSI berada di bawah rata-rata kemampuan komunikasi sosial yang diukur melalui ESCS.

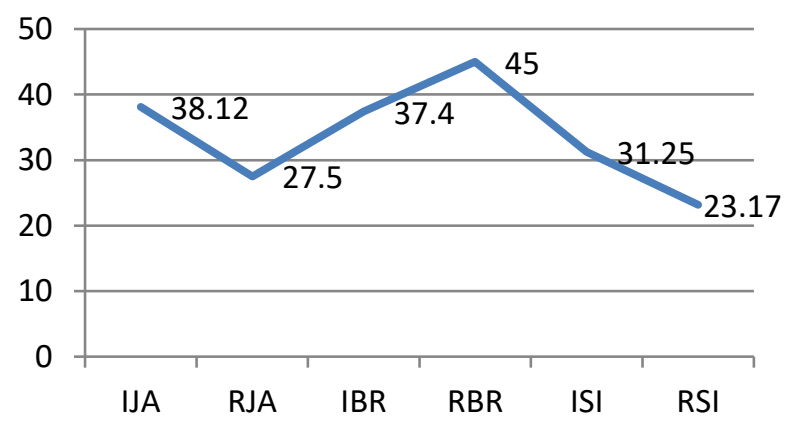

Gambar 1. Grafik hasil pengukuran ESCS saat pre-test

Tabel 2 Perbandingan Kemampuan IJA dan RJA

\begin{tabular}{ccccc}
\hline Hari & \multicolumn{3}{c}{ Joint Attention } \\
\hline & Skor & Nilai rata-rata & Skor & Nilai tengah \\
IJA & $I J A=38.12$ & RJA & RJA =27.5 \\
\hline 1 & 16.7 & $<38.12$ & 43.75 & $>27.5$ \\
2 & 22.2 & $<38.12$ & 18.75 & $<27.5$ \\
3 & 60 & $>38.12$ & 25 & $<27.5$ \\
4 & 25 & $<38.12$ & 18.75 & $<27.5$ \\
5 & 66.7 & $>38.12$ & 31.25 & $>27.5$ \\
Rata- & & & & \\
rata & $\mathbf{3 8 . 1 2}$ & & $\mathbf{2 7 . 5}$ & \\
\hline
\end{tabular}


Tabel 3. Kesimpulan Seluruh Tahap CCPT

\begin{tabular}{|c|c|c|c|c|c|c|c|c|c|}
\hline \multicolumn{2}{|c|}{ Warm-up } & \multicolumn{2}{|c|}{ Aggression and pain } & \multicolumn{2}{|c|}{$\begin{array}{l}\text { Dependence and } \\
\text { independence }\end{array}$} & \multicolumn{2}{|c|}{ Mastery } & \multicolumn{2}{|c|}{ Relationship building } \\
\hline Total & $\begin{array}{l}\text { Rata- } \\
\text { rata }\end{array}$ & Total & $\begin{array}{c}\text { Rata- } \\
\text { rata }\end{array}$ & Total & $\begin{array}{l}\text { Rata- } \\
\text { rata }\end{array}$ & Total & $\begin{array}{c}\text { Rata- } \\
\text { rata }\end{array}$ & Total & $\begin{array}{l}\text { Rata- } \\
\text { rata }\end{array}$ \\
\hline 22 & 5,5 & 116 & 23,2 & 67 & 16,75 & 53 & 13,25 & 43 & 14,3 \\
\hline
\end{tabular}

Dari tabel di atas dapat disimpulkan bahwa kemampuan Joint Attention yang mampu ditampilkan oleh subyek selama menjalani proses terapi tidak memiliki pola yang konsisten. Subyek mengalami peningkatan kemampuan JA pada tahap aggression and pain dan kemudian terjadi penuruan hingga pada tahap mastery dan kembali mengalami sedikit kenaikan pada tahap relationship building.

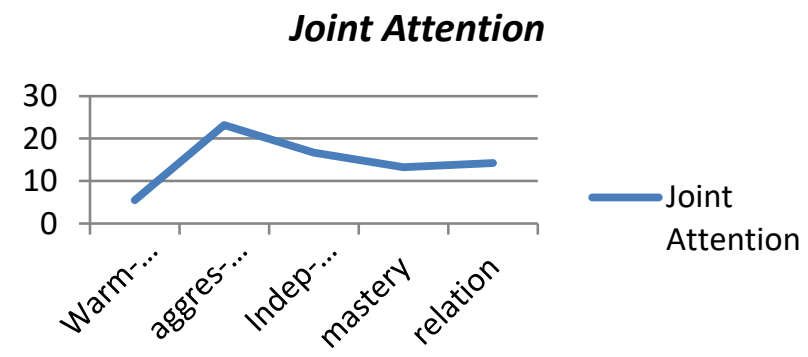

Gambar 3. Grafik kemampuan Joint Attention saat penerapan CCPT

Evaluasi sebagai post-test yang dilaksanakan pada penelitian ini menggunakan alat ukur Early Social Community Scales (ESCS). Tabel 4 menunjukkan perbandingan kemampuan subyek pada Joint Attention (JA), Behavior Request (BR), dan Social Interaction (SI).

Tabel 4. Tabel Hasil Pengukuran ESCS

\begin{tabular}{ccccc}
\hline No & Kemampuan & Hasil rata-rata & Nilai rata-rata & $\begin{array}{c}\text { Perbandingan } \\
\text { kemampuan }\end{array}$ \\
\hline 1 & IJA & 77.56 & 36.4 & $>36.4$ \\
2 & RJA & 10 & 36.4 & $<36.4$ \\
3 & IBR & 32 & 36.4 & $<36.4$ \\
4 & RBR & 56.62 & 36.4 & $>36.4$ \\
5 & ISI & 28.57 & 36.4 & $<36.4$ \\
6 & RSI & 13.85 & 36.4 & $<36.4$ \\
\hline
\end{tabular}

Dari hasil post-test diketahui bahwa kemampuan IJA dan RBR berada di atas rata-rata kemampuan komunikasi sosial yang diukur melalui ESCS, artinya kemampuan subyek untuk melakukan inisiatif perhatian bersama peneliti dan kemampuan subyek untuk merespon permintaan peneliti lebih berada diatas rata-rata kemampuan lain yang diukur dalam ESCS.

Kemampuan RJA, IBR, ISI, dan RSI berada di bawah rata-rata kemampuan komunikasi sosial yang diukur melalui ESCS, artinya kemampuan subyek untuk merespon perhatian dari peneliti, kemampuan subyek inisiatif melakukan permintaan kepada peneliti, kemampuan subyek untuk 
berinisiatif melakukan interaksi sosial kepada peneliti, dan kemampuan subyek untuk merespon interaksi sosial dari peneliti berada di bawah rata-rata kemampuan lain yang diukur dalam ESCS.

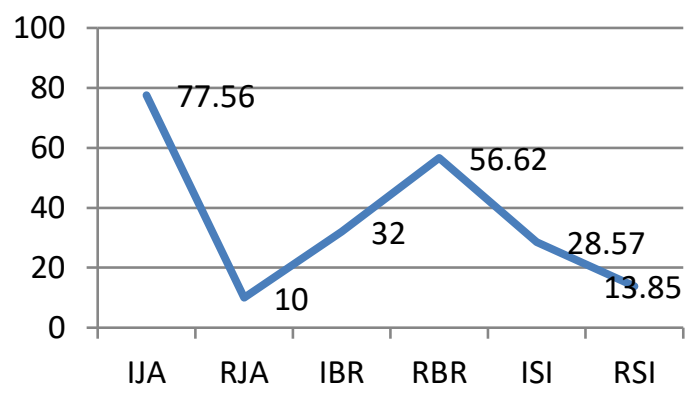

Gambar 4. Grafik hasil ESCS saat post-test

Fokus kemampuan yang ingin diketahui adalah Joint Attention (JA). Dari tabel dan grafik 4 di atas dapat diketahui bahwa kemampuan subyek dalam inisiative joint attention (IJA) lebih tinggi dari kemampuan responding joint attention (RJA). Perbandingan dalam kemampuan JA secara khusus adalah Kemampuan IJA subyek lebih tinggi (skor $=77,56$ ) dibandingkan dengan kemampuan RJA (skor $=10$ ). Hal ini berarti kemampuan subyek untuk menginisiasi berbagai perhatian dengan mitra interaktif (peneliti) lebih tinggi daripada kemampuan merespon perhatian dari mitra interaktif (peneliti) seperti yang dapat dilihat pada tabel 5 .

Tabel 5. Tabel Perbandingan Kemampuan IJA dan RJA

\begin{tabular}{ccccc}
\hline Hari & \multicolumn{4}{c}{ Joint Attention } \\
\hline & Skor & Nilai rata-rata & Skor & Nilai tengah \\
1 & $I J A$ & IJA=77,56 & RJA & RJA $=10$ \\
2 & 90 & $>77,56$ & 12,5 & $>10$ \\
3 & 87.8 & $>77,56$ & 12,5 & $>10$ \\
4 & 73 & $<77,56$ & 6,25 & $<10$ \\
5 & 73 & $<77,56$ & 12,5 & $>10$ \\
\hline Rata-rata & 64 & $<77,56$ & 6,25 & $<10$ \\
\hline
\end{tabular}

Dari hasil penelitian ini diketahui yaitu Kemampuan IJA (inisiative Joint Attention) subyek yang mengalami peningkatan skor paling tinggi adalah kemampuan memperlihatkan (show). Definisi operasional kemampuan memperlihatkan (show) menurut Early Social Communication Scale (ESCS) adalah subyek mampu melambaikan obyek ke arah peneliti dan atau mampu menolak ketika peneliti mencoba untuk mengambil obyek yang dipegang oleh subyek. Selama pengukuran (post-test) yang dilakukan melalui pemberian tugas-tugas dalam ESCS, kemampuan memperlihatkan (show) yang ditampilkan oleh subyek adalah subyek menolak ketika peneliti mencoba untuk mengambil obyek yang dipegang obyek.

Subyek secara gigih akan mempertahankan obyek (mainan) yang dia sukai dengan cara menolak memberikan mainan tersebut kepada peneliti, dan mainan yang ia sukai adalah mainan mekanik genggam (seperti mainan pop-up, squezze toy, dan mainan yang dapat dapat bergerak dengan cara memutar tombol putar ) dan mainan mekanik tiup (seperti kincir, peluit dengan kincir, dan peluit sedotan). Mainan mekanik adalah mainan yang paling disukai karena mainan tersebut dapat bergerak atau digerakkan dan mengeluarkan suara. 
Dalam CCPT, joint attention telah dieksplor sebagai area dimana anak membagi minatnya dengan terapis. Kemampuan memperlihatkan (show) dipelajari subyek saat menjalani proses treatment karena subyek diberikan kebebasan untuk menentukan permainan yang ia mainkan dan peneliti tidak memberi arahan, batasan dan instruksi apapun tentang pilihan mainan, selain itu peneliti terlibat dalam permainan bersama dengan subyek sehingga subyek merasa dapat membagi minatnya tanpa dihalangi oleh peneliti.

Salah satu pendekatan dari CCPT adalah spontanitas. Di dalam CCPT anak adalah pengendali dari setiap sesi, jadi pembentuk struktur dalam CCPT adalah anak. Mainan dan aktivitas yang digunakan merupakan pilihan dari anak pada saat sesi terapi berlangsung (Mullen \& Rickli, 2014).

Dalam proses CCPT, terapis (dalam penelitian ini adalah peneliti) bekerja untuk menciptakan sebuah lingkungan dimana anak dapat merasa aman, menyediakan sebuah kesempatan untuk mengekspresikan diri dalam cara yang paling nyaman bagi anak dan bertemu dengan level personal dari perkembangan mereka (Mullen \& Rickli, 2014).

Saat anak merasa aman, maka area aman anak dapat diperlebar dan anak dapat terlibat dalam rentang aktivitas yang lebih luas dan meningkatkan interaksi dengan terapis (Salter.K, Beamish. W, and Davies.M, 2016). Perilaku sosial yang mampu dipelajari oleh subyek adalah memperlihatkan minatnya kepada peneliti dengan cara mempertahankan mainan yang ia sukai dan menolak jika dilarang oleh peneliti.

Kemampuan untuk menunjukkan keinginan dan memutuskan apa yang ingin dilakukan merupakan kemampuan yang timbul pada usia dua tahun yang dikenal sebagai tahap autonomy versus shame and doubt. Anak usia 2 tahun cenderung ingin menahan saat mereka ingin dan mendorong atau membuang jika mereka tidak ingin. Anak melatih kemauan mereka, sense mereka untuk otonomi (mandiri), mereka seringkali menggunakan "aku, punyaku (Crain.W, 2011).

Selain kemampuan Joint Attention (JA), ditemukan beberapa perilaku lain yang terkait dengan kemampuan interaksi sosial. Perilaku interaksi sosial tersebut antara lain adalah (a) inisiatif dan respon interaksi sosial, dan (b) mengembangkan attachment dengan peneliti.

Subyek mampu melakukan inisiatif interaksi sosial dengan cara mengajak peneliti bermain cilukba, meminta digendong, duduk bersandar ke tubuh peneliti, memegang tangan peneliti, melarang peneliti untuk bermain balon dengan cara mengambil balon dari tangan peneliti. Subyek dapat mengembangkan hubungan kedekatan dengan peneliti dalam bentuk bekerjasama saat bermain dengan peneliti, mengimitasi permainan yang dilakukan oleh peneliti, mau melakukan instruksi dari peneliti dan memberikan mainan kepada peneliti saat diminta, meminta tolong kepada peneliti.

Di sisi yang lain pada penelitian ini juga terdapat penurunan, kemampuan mengikuti garis perhatian yang dilakukan selama sesi CCPT dilakukan secara spontan, sehingga pada saat posttest subyek cenderung juga melakukan secara spontan dan menolak jika mengetahui bahwa ia sedang diarahkan oleh peneliti. 


\section{KESIMPULAN DAN SARAN}

\section{Kesimpulan}

Berdasarkan hasil penelitian yang dilakukan, ditemukan bahwa Child Centered Play Therapy (CCPT) dapat meningkatkan target inisiative joint attention (IJA) dengan perbandingan skor pada saat post-test lebih tinggi $(77,56)$ dari pada skor hasil pre-test $(38,12)$. Target IJA dalam penelitian ini meliputi kontak mata, pergantian kontak mata (alternate), menunjuk (point), menunjuk dan kontak mata (point and eye contact), dan memperlihatkan (show). Pada sisi lain, hasil penelitian juga terdapat penurunan target responding joint attention (RJA) saat subyek diberikan CCPT dengan selisih skor sebesar 17,5 (post-test lebih rendah daripada skor pre-test).

\section{Saran}

Peneliti selanjutnya diharapkan dapat meneliti kemampuan joint attention pada anak yang mengalami ASD dengan memiliki usia yang berbeda. Anak autis yang memiliki usia diatas tiga tahun dengan tingkat keparahan yang sama memiliki tugas perkembangan yang berbeda baik perkembangan fisik, kognitif, dan sosial. Pihak klinik yang berkepentingan dalam penelitian ini adalah klinik terapi disarankan untuk menggunakan CCPT sebagai alternatif terapi karena CCPT dapat efektif meningkatkan kemampuan Joint Attention dan kemampuan interaksi sosial yang lain pada anak dengan ASD dengan usia tiga tahun. Pihak orangtua disarankan untuk memberikan kesempatan pada anak menjalani terapi bermain ini lebih lanjut. CCPT ini dapat terus dilakukan lebih dari satu putaran sesuai dengan perkembangan masing-masing anak.

\section{REFERENSI}

Adamson LB, \& Bakeman R. (1984). Mothers' communicative actions: Changes during infancy. Infant Behavior and Development.7, 467-478.

American Psychiatric Assosiation. (2013). Diagnostic and statistical manual of mental disorder ( $5^{\text {th }}$ ed.). Washington, DC: American Psychiatric Association Publishing.

Balch, J.W., \& Ray, D.C. (2015). Emotional assets of children with autism spectrum disorder: A single case therapeutic outcome experiment. Journal of Counseling and Development, 93., 429-439.

Bavin, E., et al. (2014). Severity of autism is related to children's language processing. International Society for Autism Research. 7 (6), 687-694.

Berk, L. E. (2013). Infants, Children, and Adolescents ( $7^{\text {th }}$ ed.) Upper Saddle River, NJ: Pearson Education, Inc.

Charman,T, \& Wendy, S (2006). Social \& Communication Development in Autism Spectrum Disorder. Early Identification, Diagnosis, and Intervention. New York, NY: 72 Spring Street

Cochran, N.H, Nordling, W.J, \& Cochran, J.L (2010). Child-centered play therapy. A practical guide to developing therapeutic relationships with children. Hoboken, NJ: John Wiley \& Sons.

Crain, W. (2011). Theories of development, concepts and applications (6th ed.). Upper Saddle River, NJ: Pearson Education, Inc.

Deckers, A, Roelofs, J., Muris, P., \& Rinck, M. (2014). Desire for social interaction in children with autism spectrum disorders. Research in Autism Spectrum Disorders, 8, 449-453.

Jeyabalan. S. (2012). Developing Joint Attention in Children with Autism Spectrum Disorder - A Pilot Study. Developing Joint Attention in Children with ASD. Bachelor of Arts in Psychology (Honours). Murdoch University, Perth, WA. 
Kaale, A., Smith, L., \& Sponheim, E. (2012). A randomized controlled trial of preschool-based joint attention intervention for children with autism. Journal of Child Psychology Psychiatry, 53(1), 97-105.

Kasari, C. Freeman, S. \& Paparella. (2006). Joint attention and symbolic play in young children with autism: A Randomized controlled intervention study. Journal of Child Psychology and Psychiatry, 47(6), 611- 620.

Kerig, P. K., Ludlow, A., \& Wenar, C. (2012). Developmental psychopathology: from infancy through adolescence ( $6^{\text {th }}$ ed.). Maidenhead, UK: McGraw-Hill.

Kring, A. M., Johnson, S. L., Davison, G. C., \& Neale, J. M. (2010). Abnormal psychology. Hoboken, NJ: John Wiley \& Sons.

Lynch, K. G. (2013). Review Response to and initiation of joint attention: overlapping but distinct roots of development in autism?. Department of Psychology, College of Staten Island, City University of New York, New York, NY.

Mash, E. J., \& Wolfe, D.A. (2013). Abnormal child psychopathology, (5th Ed). Belmont, CA: Wadsworth/ Cengage Learning.

Mellisa, F. (2013). 112.000 Anak Indonesia diperkirakan menyandang autisme. Republika. Diakses dari http://www.republika.co.id/berita/nasional/umum/13/04/09/mkz2un112000-anak-indonesia-diperkirakan-menyandang-autisme. 